\title{
Geochemical Characterization of Exposed Black Shale Sediments of Matamuhari Anticline, Bangladesh
}

\author{
Ashraf Ali Seddique ${ }^{1, ~ *, ~ N a z m u l ~ I s l a m ², ~ S h r e e ~ B i p u l e n d u ~ B a s a k ~}{ }^{1}$, Muhammad Badruzzaman ${ }^{3}$, \\ Abdul Batin ${ }^{4}$ \\ ${ }^{1}$ Department of Environmental Science and Engineering, Jatiya Kabi Kazi Nazrul Islam University, Mymensingh, Bangladesh \\ ${ }^{2}$ Department of Petroleum and Mining Engineering, Jessore University of Science and Technology, Jessore, Bangladesh \\ ${ }^{3}$ Department of Biochemistry and Molecular Biology, Bangabandhu Sheikh Mujibur Rahman Agricultural University, Gazipur, Bangladesh \\ ${ }^{4}$ Bangladesh Petroleum Exploration and Production Company Ltd., Dhaka, Bangladesh
}

\author{
Email address: \\ aseddique1975@gmail.com (A. A. Seddique) \\ ${ }^{*}$ Corresponding author
}

\section{To cite this article:}

Ashraf Ali Seddique, Nazmul Islam, Shree Bipulendu Basak, Muhammad Badruzzaman, Abdul Batin. Geochemical Characterization of Exposed Black Shale Sediments of Matamuhari Anticline, Bangladesh. International Journal of Environmental Protection and Policy. Vol. 7, No. 3, 2019, pp. 86-92. doi: 10.11648/j.ijepp.20190703.11

Received: May 31, 2019; Accepted: July 3, 2019; Published: July 19, 2019

\begin{abstract}
Matamuhari anticline is one of the largest anticline situated at Bandarban district of Bangladesh which is $60 \mathrm{~km}$ long and $20 \mathrm{~km}$ wide in the part of Bangladesh. Like other part of Bangladesh the whole sequence of exposed rocks of Matamuhari anticline is composed with Neogene sedimentary rocks of shale, sandstone, siltstone, silty shale, tabular and spheroidal calcareous concretions. Seven outcrop black shale samples were collected during February 2013 from the different parts of the anticline namely Boro Bari Jhiri, Ochir Jhiri and Tak Chara area were mineralogically and geochemically examined in order to better understand the depositional environment in the studied area. The major and trace elements were analyzed using XRF spectrometry. Two distinct lithofacies assemblages, mud and silty-clay are found in the collected sediments. The shales are predominated by quartz, kaolinite, chlorite, mica (muscovite and biotite), feldspar (both K-feldspar and plagioclase), and in addition to a variable ratio of vermiculite. Lithologial characteristics and geochemical data demonstrated that sediments are enriched with TOC contents ranging from 0.39 to $0.67 \mathrm{wt} . \%$ and shows distinctive correlation to concentration of TOC and particle size distribution. These shales are characterized by a low $\mathrm{Mg}$ and $\mathrm{K}$ as well as high $\mathrm{Al}$ and $\mathrm{Fe}$ contents. Studies also show that the values of $\mathrm{MgO} / \mathrm{Al}_{2} \mathrm{O}_{3}$ and $\mathrm{K} 2 \mathrm{O} / \mathrm{Al}_{2} \mathrm{O}_{3}$ ratio ranges from 0.15 to 0.17 and 0.18 to 0.20 respectively. The relationship of $\log \mathrm{MgO} / \mathrm{Al}_{2} \mathrm{O}_{3}$ and $\log \mathrm{K}_{2} \mathrm{O} / \mathrm{Al}_{2} \mathrm{O}_{3}$ values reveals that all of the studied samples fell within the marine environment. $\mathrm{Ni} / \mathrm{Co}$ ratio of the studied shale samples ranges from 2.84 to 3.88 (average 3.36 ). These low values of $\mathrm{Ni} / \mathrm{Co}$ ratio suggest that the sediments were deposited under oxic conditions. However, the above observations suggest that the sediments of Matamuhari anticline area were deposited in a shallow marine environment under oxic conditions.
\end{abstract}

Keywords: Matamuhari Anticline, Black Shale, Environment, Total Organic Carbon

\section{Introduction}

Matamuhari anticline is one of the largest anticline situated in the eastern and northern frontier hilly region of folded area of Bandarban, Bangladesh. Matamuhari Structure is about $150 \mathrm{~km}$ in length, but in Bangladesh part it is about $60 \mathrm{~km}$ in length and $20 \mathrm{~km}$ in width having axial trend along NNWSSE direction. It is elongated asymmetric anticline, southward to the Rakhain area of Myanmar, which is complicated due to the longitudinal and transverse fault. Matamuhari anticline has an average elevation ranges from $245 \mathrm{~m}$ to $330 \mathrm{~m}$ in the northern part, but in the southern part it increases from $410 \mathrm{~m}$ to $570 \mathrm{~m}$ and the maximum elevation is $710 \mathrm{~m}$ in the south. Matamuhari anticline is uniqueanda little amount of work has been done on it. Geological survey party of Bangladesh Petroleum Exploration and Production Company Ltd. (BAPEX) worked there to find out the 
geological feature, collect rock samples for petrophysical study [1]. Before 1999, the dispositional environment of the exposed rock throughout the southern fold belt of Bengal Basin of the Neocene Surma group was thought Deltaic to Shallow marine. However, [4-7] revises the earlier views and proposed that the lower Surma group succession represents an overall basinward propogradation from deep marine to coastal marine depositional settings. Based on sedimentological evidences [3] has suggested that the lower Surma group represents a slope apron the growth of which is thought to have been governed by westward migrating acceretionary prism complex within the active margin setting of the Indo Burmese plate convergence. Comparable deepsea clastics with thicker intervals of sandstone turbidities contained within a submarine canyon are present in the Mirinja anticline. Alam, et al. (2003) also gives an overview regarding the sedimentary geology of the Chittagong-Tripura Fold Belt (CTFB) and shows a stratigraphic classification for the CTFB that has been established for four groups [2]. Matamuhari anticline fall into the Mirinja Group which is analogous under the traditional upper Surma Group and this group has possibly the thickness ranges from $1200 \mathrm{~m}$ to 1600 $\mathrm{m}$ [2]. It is interesting to get more information about the shale facies as one of the most important oil and gas source rocks. Thereafter, this study will focus on (i) to draw a general picture of geochemical characteristics of exposed black shale sediments, and (ii) to better understand the depositional environment in the area studied.

\subsection{Area of Investigation}

The study was conducted in Lama, Alikadam and Naikhangchari Upazilla of Bandarban at South-Eastern part of Bangladesh. The studied area encompasses mostly Neogene Hills of Matamuhari anticline. The study area lies between $21^{\circ} 34^{\prime} \mathrm{N}$ to $21^{\circ} 45^{\prime} \mathrm{N}$ latitude and $92^{\circ} 04^{\prime} \mathrm{E}$ to $92^{\circ} 19^{\prime} \mathrm{E}$ longitude (Figure 1a). The area is bounded by Matamuhari River to the north and east, Cox's Bazar to the west and Rakhaing of Myanmar to the south (Figure 2). The accessibility of the area is trouble- free in the northern part of the structure, but very tough in the southern part. The study area is in tropical climatic region and receives heavy rainfalls during monsoon. The extent of rainfalls take place during the monsoon that prevails month of June to September. The maximum average temperature is about $32^{\circ} \mathrm{C}$ which prevails in the month between April and May weather the minimum average temperature is $13^{\circ} \mathrm{C}$ which prevails in the month of December. The intense rainfall is the main cause of developing abundant growth of vegetation in the study area (Figure 1b). The entire hilly area is covered with dense mixed forest with a variety of trees and wide number of bamboos, shrubs and herbs.
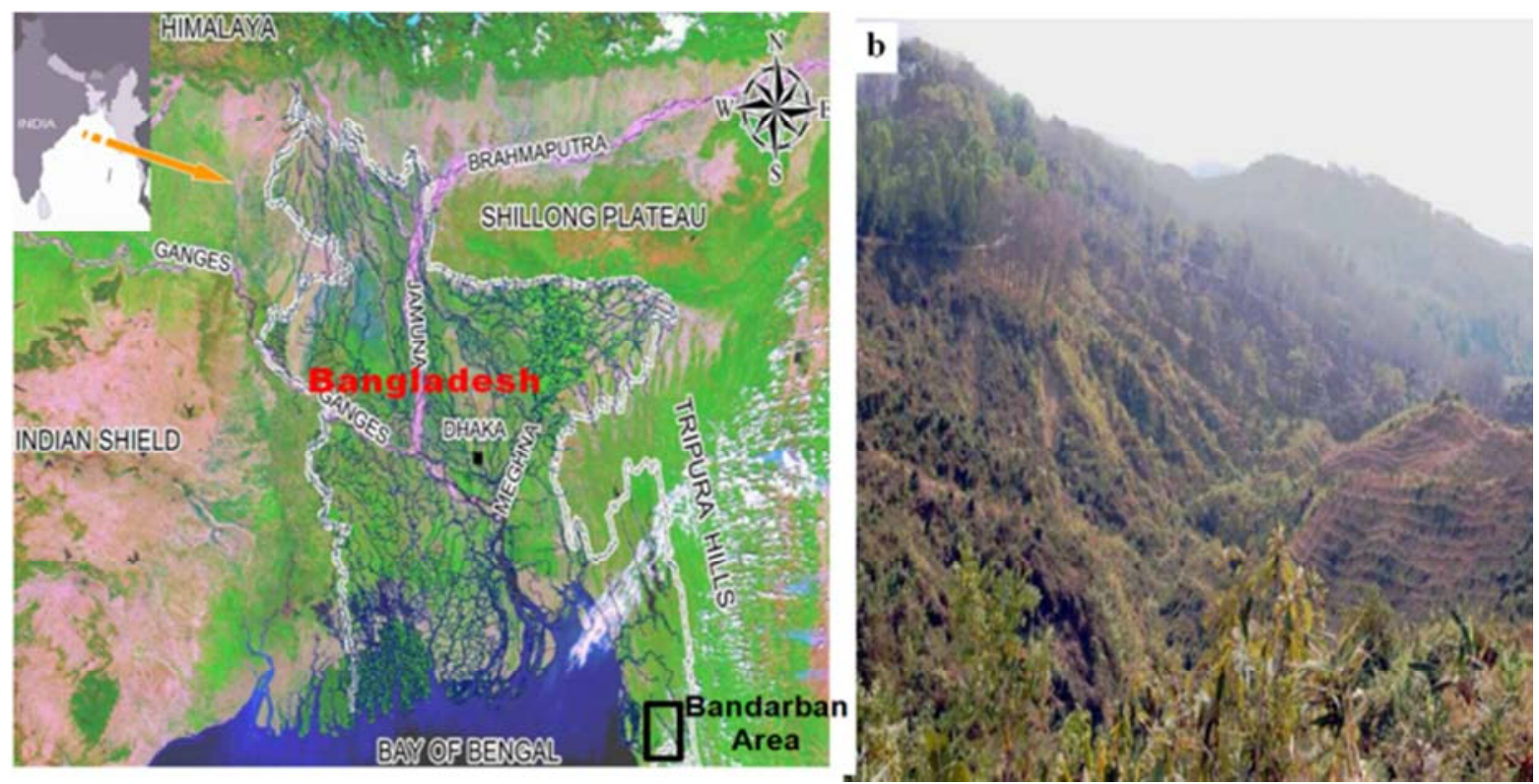

Figure 1. (a) Map showing the location of Bandarban study site in the South-Eastern part of the Folded Belt and location of the study area is indicated by a small rectangle;(b) Photograph showing the sky view of Neogene Hills of Matamuhari anticline.

\subsection{Geological and Tectonic Setting of the Study Area}

Matamuhari Structure is situated in the southern part of Eastern Folded Belt in Bengal Foredeep mainly comprises of Neogene Sedimentary rocks. It is located in between Bandarban structure in the east and Olatang structure in the southwest [8]. The development of Matamuhari structure is contemporaneous to the formation of Bengal Foredeep and is affected by faulting like as the other structure of Chittagong-
Tripura Fold Belt (CTFB) [4, 5]. The Matamuhari structure is narrow and elongated with steeper eastern flank than the western flank (Figure 2a \& b). The tectonic and structural development of this region is more readily explained by accretionary prism formation [6]. Like other parts of Bangladesh the whole sequence of exposed rocks of Matamuhari structure is composed with Sedimentary rocks. The dominant lithology comprised of shale, sandstone, siltstone, silty shale, intraformational conglomerate and 
tabular and spheroidal calcareous concretions of Neogene sediments $[4,5]$. Argillaceous rocks occupy the bulk volume of stratigraphic columns with little coverage of arenaceous rocks. Details section wise lithology was studied and lithological columns were produced. However, the columns were correlated and divided into eight units primarily based on lithological features (Table 1). Those lithological units are Dupitila Sandstone, Girujan Clay, Tipam Sandstone, Upper Boka Bil Shale, Middle Boka Bil Sandstone, Lower Boka Bil Shale, Upper Bhuban Sandstone, and Middle Bhuban Shale from younger to older in order.

Table 1. Correlation of the Local stratigraphy with traditional stratigraphy (personal communication, BAPEX).

\begin{tabular}{|c|c|c|c|c|c|c|c|}
\hline \multicolumn{4}{|c|}{ Regional (CTFB) Nomenclature } & \multicolumn{4}{|c|}{ Nomenclature for the Matamuhari Anticline } \\
\hline Age & Group & Formation & Thickness (m) & Age & Group & Formation & Thickness (m) \\
\hline Recent & Holocene & Alluvium & & Recent & Holocene & Alluvium & \\
\hline \multirow{3}{*}{ Plio-Pleistocene } & Dupitila & Dupitila & 500 & \multirow{3}{*}{$\begin{array}{l}\text { Pliocene - } \\
\text { Pleistocene }\end{array}$} & Dupitila & Dupitila Sandstone & $300-520$ \\
\hline & Tinam Groun & Girujan Clay & 350 & & \multirow{2}{*}{ TipamGroup } & Girujan Clay & $160-410$ \\
\hline & Iıpam Group & Tipam Sandstone & 900 & & & Tipam Sandstone & $180-470$ \\
\hline \multirow{4}{*}{ Miocene } & \multirow{4}{*}{ Surma Group } & & & \multirow{4}{*}{ Miocene } & \multirow{4}{*}{ Surma Group } & Upper Bokabil Shale & $260-550$ \\
\hline & & Bokabil & 1200 & & & Middle Bokabil Sandstone & $230-700$ \\
\hline & & & & & & Lower Bokabil Shale & $370-860$ \\
\hline & & Bhuban & $3000+$ & & & $\begin{array}{l}\text { Upper Bhuban Sandstone } \\
\text { Middle Bhuban Shale }\end{array}$ & $\begin{array}{l}500+ \\
300-520\end{array}$ \\
\hline
\end{tabular}
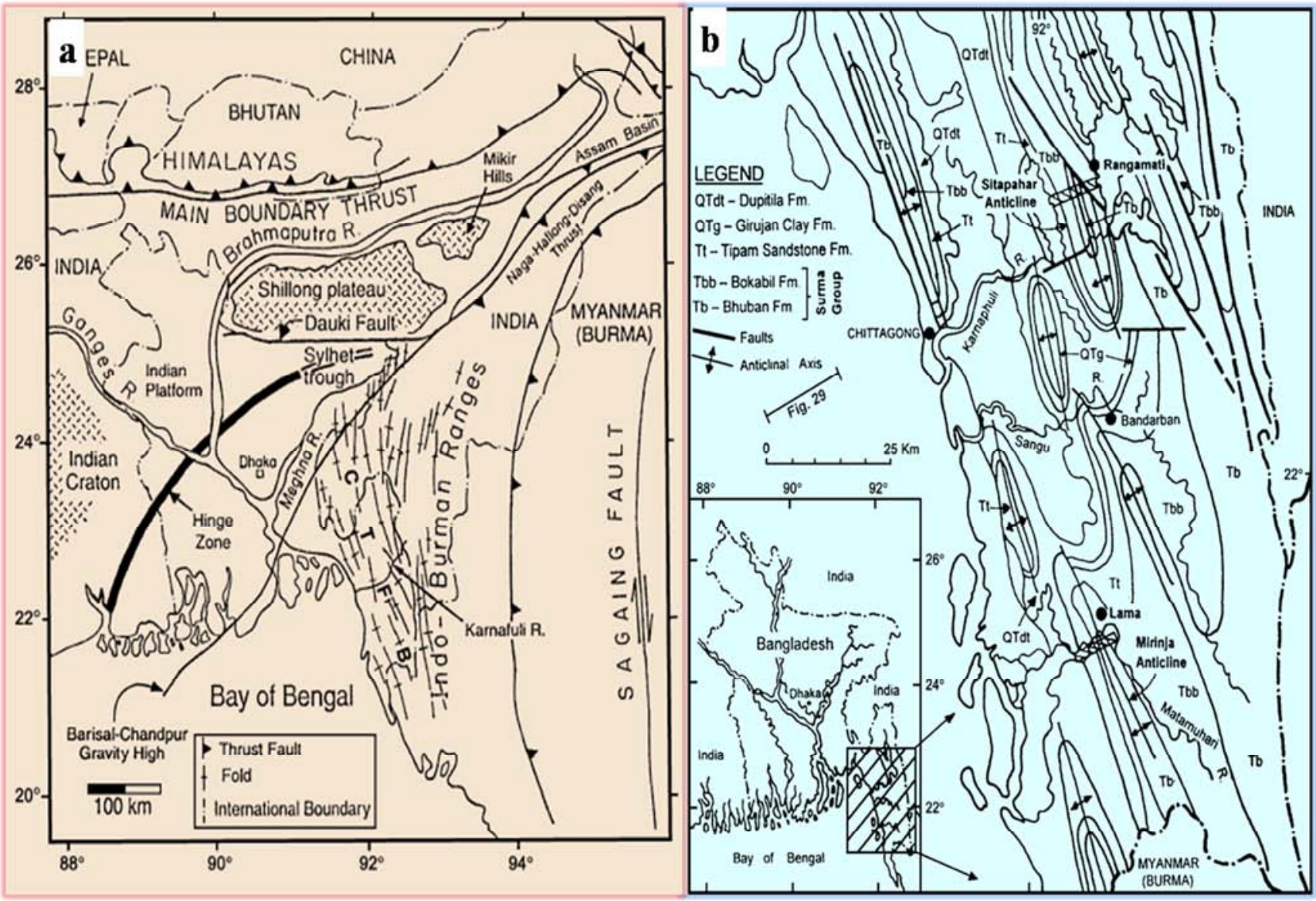

Figure 2. (a) Regional tectonic setting of the Bengal Basin showing location of the study area within the Chittagong-Tripura Fold Belt (CTFB) (after Johnson and Alam, 1991);(b) Geological sketch map of part of the Matamuhari anticline and adjacent Structure (modified after Alam etal., 2003).

\section{Materials and Methods}

\subsection{Sample Collection}

With the help of satellite image, the sampling location was selected and seven outcrop black shale samples were collected during Feb. 2013 from the different parts of the anticline such as Boro Bari Jhiri (TCB-01, BBJ-01), Ochir Jhiri (OJ-02, OJ-03) and Tak Chara (TC-01, TC-02, TC-03) area to the depth of $26 \mathrm{~cm}$ below the surface to avoid weathered outcrop (Figure 3). Undisturbed sediment cores were collected from the Bokabil formation shale of Surma group by penetration of a $3.5 \mathrm{~cm}$ diameter split-barrel sampler (Raymond sampler) by a private drilling company (Eastern 
Geotechnical, Dhaka). Samples were immediately vacuumpacked in $\mathrm{O}_{2}$-impermeable film bags (Escal film, Mitsubishi Gas Chemical Co., Japan) with deoxidizer. Later these sample were kept in the laboratory of Jessore University of Science and Technology freezer $\left(-18^{\circ} \mathrm{C}\right)$ unit analysis.

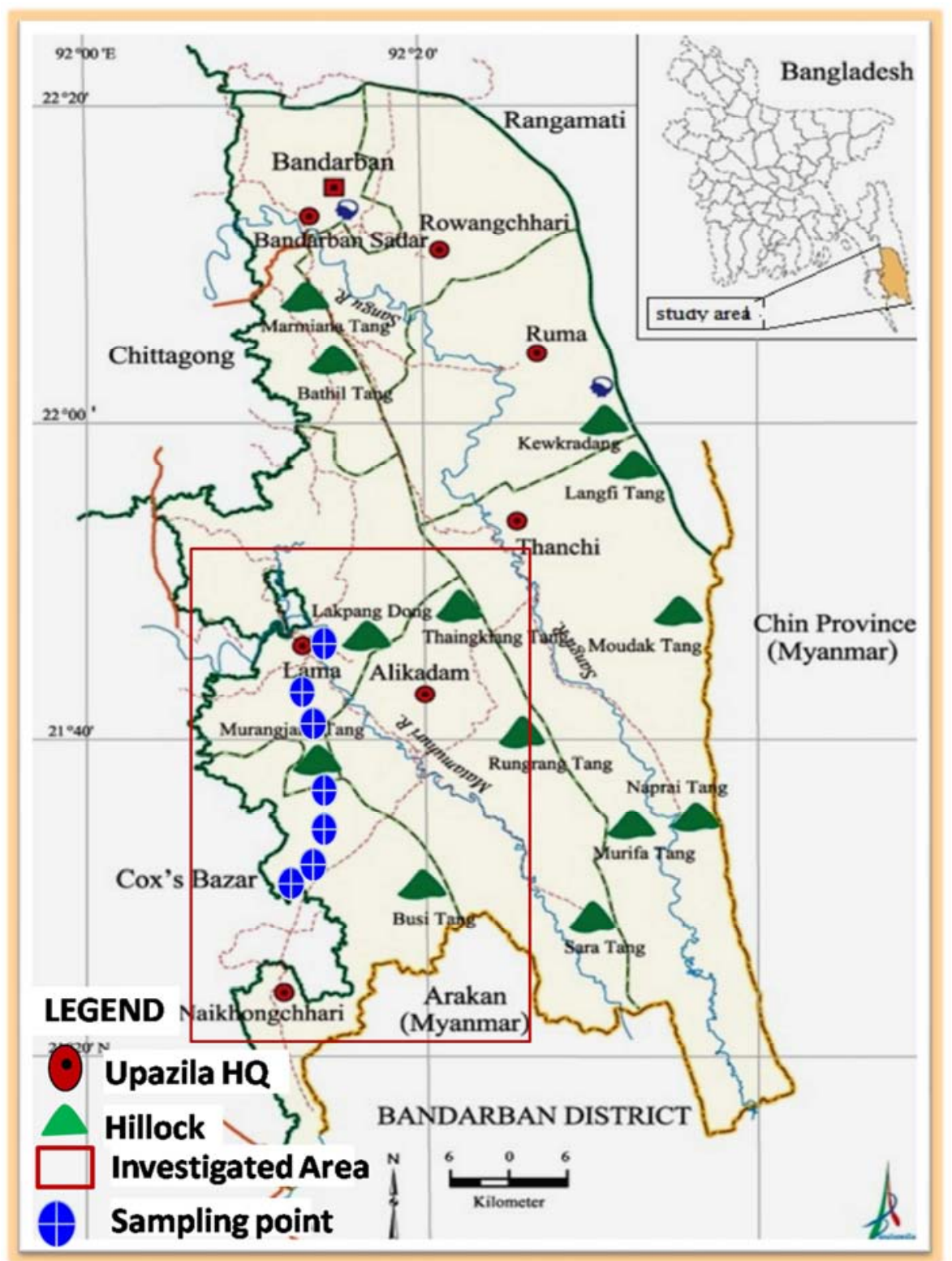

Figure 3. Enlarged topographic map of the study area showing the location of sediment sampling sites (Figure modified after Banglapedia, http://en.banglapedia.org).

\subsection{Grain Size, Bulk Mineralogy, and Major Chemistry}

Prior to analysis, about $50 \mathrm{~g}$ of undisturbed sediment core was immediately transferred from the freezer $\left(-18^{0} \mathrm{C}\right)$ to a vacuum drying oven (Advantec, VO-320) in order to avoid oxidation of the reduced compounds, and freeze dried. The dried samples were ground gently by hand with an agate mortar and pestle, and used for the analyses outlined. Grain size distribution was determined by laser diffraction and scattering spectroscopy (SALD-3000S, Shimadzu) after dispersion of the samples in sodium hexametaphosphate solution. The reproducibility of the results for the duplicate samples was within $\pm 5 \%$ at maximum. Bulk mineralogy of the sediments was identified by X-ray powder diffraction
(XRD) using a Rigaku Geigerflex instrument (RAD-IA system) with $\mathrm{Ni}$ filtered $\mathrm{Cu} \mathrm{Ka}$ radiation $(30 \mathrm{kV}, 10 \mathrm{~mA})$, operating in step scan mode, over an angular range of $2^{0}$ to $65^{\circ} 2 \theta$ with $0.02^{0} 2 \theta$ steps and a 2 s count time on $200 \mathrm{mg}$ unoriented side-packed powder mounts. Approximate relative abundance ratios of major minerals were estimated from the relative intensities of the most intense and specific peak of each mineral from an XRD chart. The major chemical composition of bulk sediments were determined by X-ray fluorescence (XRF) photometry (VXQ-160S, Shimadzu) using glass bead samples, which were prepared by fusion of sediment samples with lithium borate (1:3 ratio). The analytical errors for major elements were within $\pm 3 \%$. 


\subsection{TOC Analysis}

Total Organic Carbon of bulk sediment samples was measured by dry combustion according to a method described by [14] using an elemental analyzer (FLASH EA1112 series, IRMS) after $\mathrm{HCl}$ digestion. Analytical precision for duplicate samples was within $\pm 5 \%$.

\section{Result and Discussion}

\subsection{Sediment Characteristics}

Two distinct lithofacies assemblages, mud (clayey-silt) and silty-clay are found in the collected sediments. The sediments consist dominantly of dark gray to black thinly parallel laminated clayey-silt with mean grain diameter of $<22 \mu \mathrm{m}$, except the sediments collected from Ochir Jhiriarea with mean grain diameter $<40 \mu \mathrm{m}$. The collected sediments were pale soft, sticky and soapy feel when wet.

\subsection{Mineral Species and Their Relative Abundance Identified by XRD}

Based on XRD analysis, abundant quartz was found in every sample, and clay minerals (mainly kaolinite), mica (muscovite and biotite), feldspar (both K-feldspar and plagioclase), chlorite and minor vermiculite were observed in the silty-clay sediments (Figure 4). Although the mineral assemblages in the clayey-silt sediments were similar to those of silty-clay sediments, but small amount of illite was also identified.

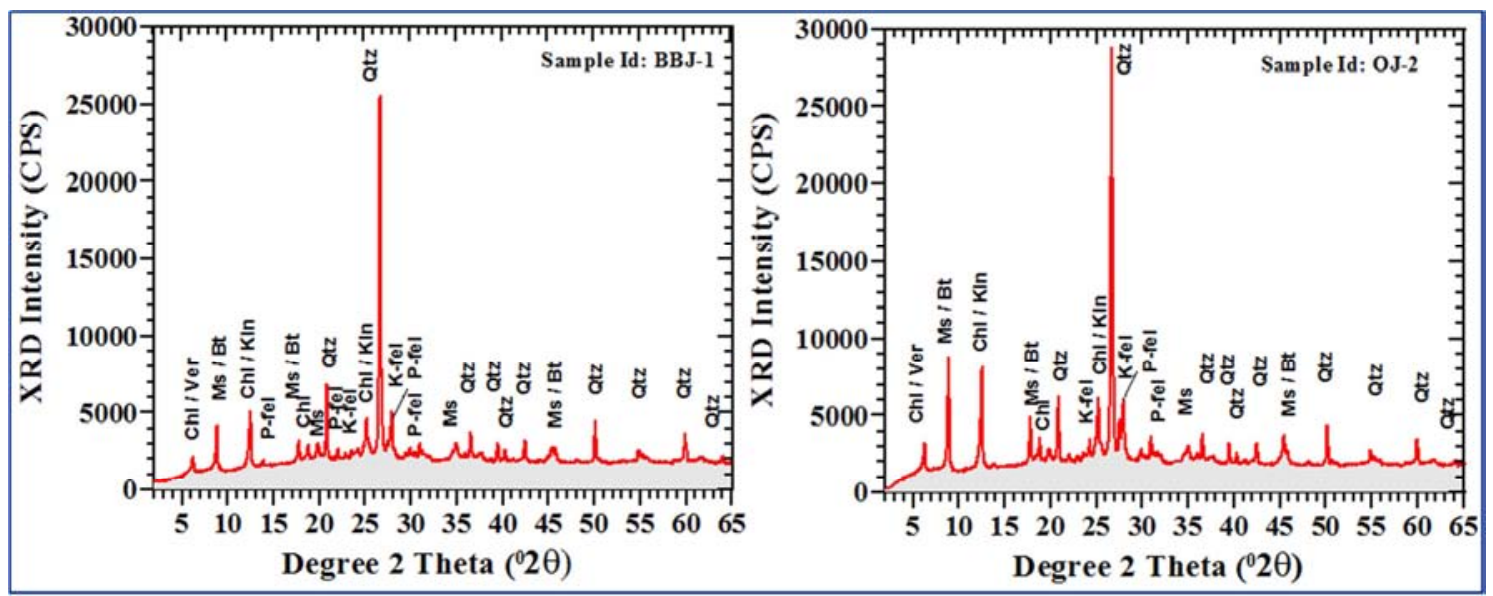

Figure 4. Powder X-ray diffraction charts of two typical silty-clay (Sample Id: QJ-2) and clayey-silt (Sample Id: BBJ-1) sediments. Qtz: quartz, Bt: biotite, Ms: muscovite, Kln: kaolinite, Chl: chlorite, Ver: vermiculite, Kfel: Potash feldspar, P-fel; Plagioclase feldspar.

\subsection{Organic Richness}

The organic richness represented by the total organic carbon (TOC) ranges from 0.39 to 0.67 wt.\%. The studied samples lie in the poor to fair organic richness of the studied samples zone (Figure 5) $[8,11,12]$. It is also noted TOC is generally low in the studied sediment column, in which most of the samples contain $<0.50 \mathrm{wt} \%$ except one sample (TC01 ), which is rich in TOC with the maximum concentration of 0.67 wt. $\%$ and no intervals rich in carbonaceous matter (e.g., peat) were apparent in the studied samples.

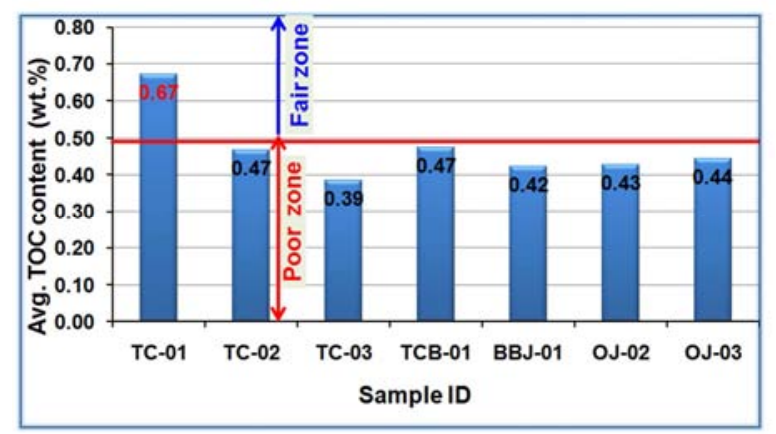

Figure 5. Organic richness i.e., average TOC wt.\% content in the studied sediments.

\subsection{Major Inorganic Geochemistry}

Geochemical signatures of clastic sedimentary rocks provide important sources of information that record different aspects of provenance and environments of deposition. The frequencies of the chemical components of the studied shale samples are shown in (Figure 6). Chemical composition was associated with mineral composition. As shown in Figure 7, the content of major inorganic constituents of all of shale samples is almost similar and uniformly distributed.

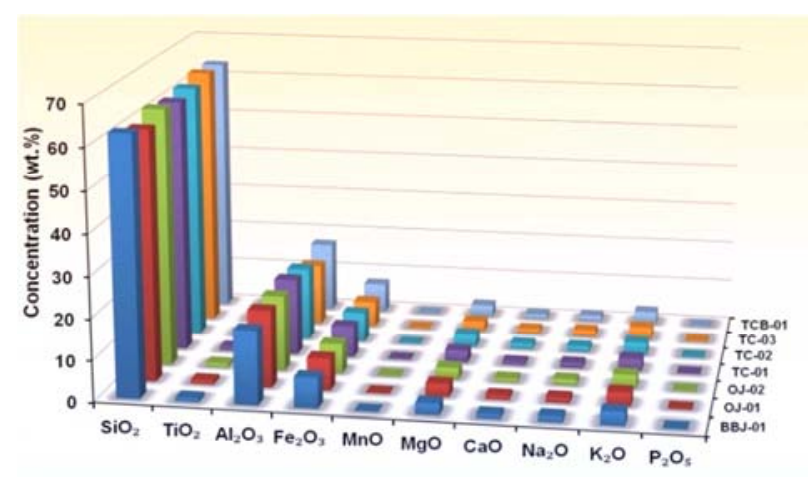

Figure 6. Showing the concentration of some major inorganic components of the studied sediments. 
Comparison of these data with the published average upper continental crust (UCC) [15]. (Table 2) illustrates that the studied shales are within the range of $\mathrm{SiO}_{2}, \mathrm{Mn}$, and $\mathrm{Mg}$; with higher contents of $\mathrm{Al}, \mathrm{Ti}$, and $\mathrm{Fe}$ while their contents of $\mathrm{Ca}, \mathrm{Na}$ and $\mathrm{K}$ are lower than the UCC data.
The higher $\mathrm{Al}$ and $\mathrm{Fe}$ content may indicate fineness in grain size and presence of clay minerals, especially kaolinite and chlorite; while the lower content of $\mathrm{K}$ may indicate marine condition [12].

Table 2. Major and trace element concentrations of the studied shale samples. Average upper continental crust (UCC) from [15].

\begin{tabular}{|c|c|c|c|c|c|c|c|c|}
\hline Elements & BBJ-01 & OJ-01 & OJ-02 & TC-01 & TC-02 & TC-03 & TCB-01 & UCC(wt.\%) \\
\hline $\mathrm{SiO}_{2}$ (wt.\%) & 62.83 & 60.91 & 62.85 & 61.8 & 62.52 & 63.7 & 63.41 & 66 \\
\hline $\mathrm{TiO}_{2}$ (wt.\%) & 0.9 & 0.95 & 0.92 & 0.95 & 0.91 & 0.8 & 0.93 & 0.5 \\
\hline $\mathrm{Al}_{2} \mathrm{O}_{3}$ (wt.\%) & 17.95 & 18.84 & 18.44 & 18.8 & 17.82 & 15.14 & 17.07 & 15.2 \\
\hline $\mathrm{Fe}_{2} \mathrm{O}_{3}($ wt. $\%)$ & 7.42 & 7.91 & 7.29 & 7.74 & 7.21 & 6.27 & 7.21 & 4.5 \\
\hline $\mathrm{MnO}($ wt.\%) & 0.08 & 0.13 & 0.1 & 0.11 & 0.1 & 0.08 & 0.11 & 0.1 \\
\hline $\mathrm{MgO}($ wt.\%) & 2.77 & 3.12 & 2.8 & 2.96 & 2.98 & 2.42 & 2.87 & 2.2 \\
\hline $\mathrm{CaO}$ (wt.\%) & 0.98 & 1.02 & 0.86 & 0.8 & 1.36 & 1.15 & 1.09 & 4.2 \\
\hline $\mathrm{K}_{2} \mathrm{O}($ wt.\%) & 3.21 & 3.38 & 3.3 & 3.09 & 3.13 & 2.96 & 3.12 & 3.4 \\
\hline $\mathrm{P}_{2} \mathrm{O}_{5}(w t . \%)$ & 0.14 & 0.16 & 0.15 & 0.15 & 0.15 & 0.14 & 0.17 & - \\
\hline $\mathrm{Co}(\mathrm{ppm})$ & 22.2 & 21.1 & 20.5 & 22.5 & 18.5 & 18.2 & 19.2 & 10 \\
\hline Ni(ppm) & 76 & 81.9 & 75.2 & 83.2 & 65.8 & 51.6 & 71 & 20 \\
\hline $\mathrm{Ni} / \mathrm{Co}$ & 3.42 & 3.88 & 3.67 & 3.7 & 3.56 & 2.84 & 3.7 & 2 \\
\hline
\end{tabular}

\section{Depositional Environment}

The relationship between $\mathrm{MgO} / \mathrm{Al}_{2} \mathrm{O}_{3}$ and $\mathrm{K}_{2} \mathrm{O} / \mathrm{Al}_{2} \mathrm{O}_{3}$ was used by Roaldest (1978) to differentiate between marine and non-marine clay [13]. The value of $\mathrm{MgO} / \mathrm{Al}_{2} \mathrm{O}_{3}$ and $\mathrm{K}_{2} \mathrm{O} / \mathrm{Al}_{2} \mathrm{O}_{3}$ ranges from 0.15 to 0.170 .18 to 0.20 respectively. Application of this relation on the studied black shales (Figure 7) revealed that all the studied samples fell within the marine environment. According to Jones and Manning (1994) values of $\mathrm{Ni} / \mathrm{Co}$ ratio ranges from below 5 indicate oxic environment whereas values above 5 suggest suboxic and anoxic environment [10]. Ni/Co ratio of the studied shale samples ranges from 2.84 to 3.88 (avg. 3.36) (Table 2). These low values of $\mathrm{Ni} / \mathrm{Co}$ ratio suggest deposition under oxic conditions. Thereafter, it is suggested that the studied shales were deposited in a shallow marine environment under oxic conditions.

\section{Conclusion}

Two distinct lithofacies assemblages, i.e. clayey-silt and silty-clay are found in the collected Bokabil black shales sediments. Lithologial characteristics and geochemical data demonstrated that the sediments are enriched with TOC contents ranging from 0.39 to $0.67 \mathrm{wt} . \%$ and show distinctive correlation to concentration of $\mathrm{TOC}$ and particle size distribution. The mineralogical composition of the studied sediments is predominated quartz, kaolinite, chlorite, mica (muscovite and biotite), feldspar (both K-feldspar and plagioclase), and in addition to a variable ratio of vermiculite and illite. These shales are characterized by a low $\mathrm{Mg}$ and $\mathrm{K}$ as well as high $\mathrm{Al}$ and $\mathrm{Fe}$ contents indicating that they were formed through intensive weathering of intermediate and mafic igneous rocks [12]. Mineralogical and geochemical studies (organic and inorganic) indicate deposition of these shales under a shallow marine environment with some terrestrial input. The studied shales have poor to fair organic richness. They indicate the capability to produce gas and fair oil source.

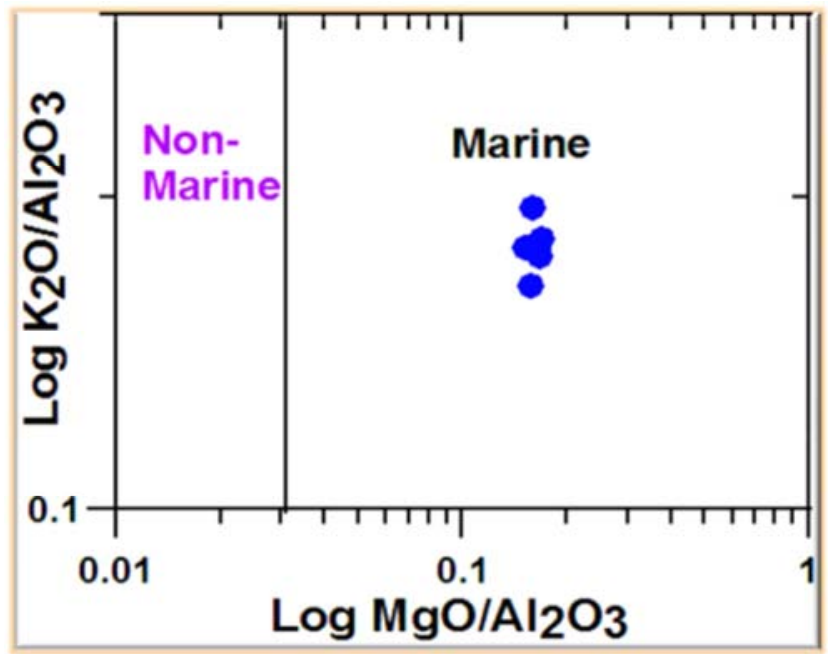

Figure 7. Depositional environment diagram on $\log \left(\mathrm{MgO} / \mathrm{Al}_{2} \mathrm{O}_{3}\right)$ and $\log \left(\mathrm{K}_{2} \mathrm{O} / \mathrm{Al}_{2} \mathrm{O}_{3}\right)$ (after Roaldest, 1978).

\section{Acknowledgements}

The authors would like to thank Dr. Yoshiaki Kon, Geological Survey of Japan, for assistance with the laboratory analyses. Dr. M. Mitamura gave useful suggestions to improve the first draft of manuscript. The authors are also grateful to Chief Editor and two anonymous reviewers for their constructive comments and suggestions that improved the manuscript. Special thanks are due to $\mathrm{Mr}$. Gazi Tawfiq Ezaz, Md. Ariful Islamand S. K. Sabbir Hossain for their technical support. 


\section{References}

[1] Ahmed S., Uddin M. N., Batin M. A., (2012). Geological Report on Matamuhari Anticline.

[2] Alam, M., Alam, M. M., Curray, J. R., Chowdhury, M. L. R., Gani, M. R., (2003). An overview of the sedimentary geology of the Bengal basin in relation to the regional tectonic framework and basin-fill history. Sediment. Geol. 155, 179208.

[3] Alam, M. M., and Karim, S. M. R., (1997). Facies and environmental analysis of the Neogene (Surma Group) clastic succession in the Mirinja anticline, Folded Belt of the Bengal Basin, Bangladesh. Bangladesh Geosci. J. 3, 19-32.

[4] Evans, P., (1932). Tertiary succession in Assam. Trans. Min. Geol. Inst. India 27, 155-260.

[5] Khan, F. H. (1991). Geology of Bangladesh, Wiley, New Delhi. 207pp.

[6] Gani, M. R., and Alam, M. M., (1999). Trench-slope controlled deep-sea clastics in the exposed Surma Group in the southeastern fold belt of the Bengal Basin, Bangladesh. Sediment. Geol. 127, 221-236.

[7] Gani, M. R., and Alam, M. M., (2003). Sedimentation and basin-fill history of the Neogene clastic succession exposed in the southeastern fold belt of the Bengal Basin, Bangladesh: a high-resolution sequence stratigraphic approach, Sedimentary Geology 155, 227-270.

[8] Gulbay R. K., Kırmac1 M. Z., Korkmaz S., (2012). Organic geochemistry and depositional environment of the Aptian bituminous limestone in the Kale Gumus_hane area (NE-
Turkey): An example of lacustrine deposits on the platform carbonate sequence. Organic Geochem. 49, 6-17.

[9] Johnson, S. Y., and Alam, A. M. N., (1991). Sedimentation and tectonics of the Sylhet Trough, Bangladesh. Geol. Soc. Am. Bull. 103, 1513-1527.

[10] Jones B., Manning D. C., (1994). Comparison of geochemical indices used for the interpretation of palaeoredox conditions in ancient mudstones. Chem. Geol. 111, 111-129.

[11] Jarvie, D. M., (1993). Total organic carbon (TOC) analysis. In: Merrill, R. K. (Ed.), Source and Migration Processes and Evaluation Techniques. AAPG, Tulsa, Oklahoma, pp. 113118 .

[12] Mousa A. D., Abdou A. A., El Gendy H. N., Shehata G. M., Kassab A. M., Abuhagaza A. A. (2014). Mineralogical, geochemical and hydrocarbon potential of subsurface Cretaceous shales, Northern Western Desert, Egypt. Egyptian Journal of Petroleum 23, 67-78.

[13] E. Roaldest (1978). Mineralogical and chemical changes during weathering, transportation and sedimentation in different environments with particular references to the distribution of Yttrium and lanthanide elements (Ph.D. thesis), Geol. Inst., Univ. of Oslo, Norway.

[14] Seddique, A. A., Masuda, H., Mitamura, M., Shinoda, K., Yamanakam T., Itai, T., Maruoka, T., Uesugi, K., Ahmed K. M., Biswas, D. K. (2008). Arsenic release from biotite into a Holocene groundwater aquifer in Bangladesh. Applied Geochemistry. 23, 2236-2248.

[15] Taylor S. R, and McLennan S. M (1985). The continental crust: its composition and evolution. Blackwell Scientific Publication, Carlton, $312 \mathrm{p}$. 